\title{
Biometric evaluation of Criollo horses participating in the Freio de Ouro competition, Brazil
}

\author{
Anelise Maria Hammes Pimentel ${ }^{1}$, João Ricardo Malheiros de Souza ${ }^{*}$ (iD, Arione Augusti \\ Boligon ${ }^{1}$, Heden Luiz Marques Moreira ${ }^{3}$, Cláudio Alves Pimentel ${ }^{4}$, Charles Ferreira Martins ${ }^{5}$ \\ 1 Universidade Federal de Pelotas, Faculdade de Agronomia Eliseu Maciel, Departamento de Zootecnia, Campus Capão do Leão, Capão do \\ Leão, RS, Brasil. \\ 2 Universidade Federal de Santa Maria, Programa de Pós-graduação em Medicina Veterinária, Santa Maria, RS, Brasil. \\ 3 Universidade Federal de Pelotas, Instituto de Biologia, Campus Capão do Leão, Capão do Leão, RS, Brasil. \\ ${ }^{4}$ Universidade Federal de Pelotas, Faculdade de Veterinária, Departamento de Patologia Animal, Campus Capão do Leão, Capão do Leão, \\ RS, Brasil. \\ ${ }^{5}$ Universidade Federal de Pelotas, Faculdade de Veterinária, Departamento de Clínicas Veterinária, Campus Capão do Leão, Capão do Leão, \\ RS, Brasil.
}

ABSTRACT - The objective of this study was to quantify linear and angular morphological measurements of male and female horses participating in the Freio de Ouro competition. This study represents the first scientific evaluation of the biometrics of the Criollo breed, providing essential information for the evaluation of the development of the breed and supporting objective selection. We examined linear and angular measurements of 634 Criollo horses participating in the Freio de Ouro competition in 2011 and 2012, including height, chest circumference, cannon bone circumference, body length, metatarsus length, croup length, chest width, head length, dorsal neck length, throat circumference, and angles of the croup, scapula, and hock. Statistical analysis showed that males had a greater average cannon bone circumference $(19.76 \mathrm{~cm})$ than females $(18.95 \mathrm{~cm})$ and a greater throat circumference $(77.66 \mathrm{~cm}$ for males and $73.30 \mathrm{~cm}$ for females). None of the other traits evaluated differed between genders. The average height (141.73 cm for males and $141.41 \mathrm{~cm}$ for females) was close to the minimum requirement for the breed standard. Subjective observations suggesting that animals of this breed are decreasing in size were not confirmed in this study, as the height and other evaluated measures did not differ between competing horses less or more than seven years of age. Although these measurements in isolation do not indicate the qualities of individual animals, they serve as valuable auxiliary elements for selection work, showing breed tendencies and providing objective data to support technical decisions of judges regarding conformation.

Key Words: animal production, breed, equine, horse, morphometry

\section{Introduction}

The Criollo breed of horses is one of the most common horse breeds, with over 400,000 registered animals in Brazil and other South American countries, France, and the United States. This breed has great socioeconomic importance in Brazil and is responsible for transactions totaling R $\$ 1.28$ billion annually and $>200,000$ jobs (Lima and Cintra, 2015).

The Criollo breed was developed in the southern part of South America. Its official genealogical registry started in Brazil in 1932 with the foundation of the Associação Brasileira de Criadores de Cavalos Crioulos (ABCCC).

Received: November 16, 2017

Accepted: April 3, 2018

*Corresponding author: joao.rms@gmail.com

Copyright (C) 2018 Sociedade Brasileira de Zootecnia. This is an Open Access article distributed under the terms of the Creative Commons Attribution License (http://creativecommons.org/licenses/by/4.0/), which permits unrestricted use, distribution, and reproduction in any medium, provided the original work is properly cited.
At that time, an inspection commission visited farms to collect horses that were the product of 400 years of natural selection to serve as the breed standard: medium-sized, muscular animals with broad chests, a firm top line, a strong croup, a small head, and full tail and mane (Affonso and Correa, 1992; Dalto, 2006).

The ABCCC breed standard states that height, chest circumference, and cannon bone circumference are required body measurements for registration. For males, the requirements include height of 140.0 to $150.0 \mathrm{~cm}$, chest circumference of at least $168.0 \mathrm{~cm}$, and cannon bone circumference of at least $18.0 \mathrm{~cm}$. For females, the requirements include height of 138.0 to $148.0 \mathrm{~cm}$, chest circumference of at least $170.0 \mathrm{~cm}$, and cannon bone circumference of at least $17.0 \mathrm{~cm}$ (ABCCC, 2016). Other equally important qualities or morphological faults are assessed by intuitive observations. The lack of deductive information is a problem for other equine breeds as well (Beeman, 2008; Lage et al., 2009; Mawdsley et al., 1996). 
The objective of this study was to quantify linear and angular morphological measurements of horses participating in the Freio de Ouro competition, which is considered the most important competition for the Criollo breed. As these measurements are not registered anywhere, our findings provide an initial record of the morphology of the breed and will reduce subjectivity and variability in judgments regarding this breed.

\section{Material and Methods}

Research on animals was conducted according to the Ethics and Welfare Committee (CEEA; case no. 3.943). All techniques used in this study were non-invasive.

We measured 634 Criollo horses during admission to the 11 qualifying and final events of the 2011 and 2012 Freio de Ouro competitions (501 animals in Rio Grande do Sul, 56 in Santa Catarina, 29 in Paraná, and 48 in the Distrito Federal states). Linear and angular measurements were taken at the time of admission for each event, on the left side, as the animals stood still with their four hooves planted on a horizontal and regular floor. The measurements were obtained using a tape measure, except for height, which was measured using a horse measuring stick at the highest point of the interscapular region, located in the space defined by the T5 spinous process and the ground. The chest circumference was measured just behind the withers, from the T8 and T9 spinous processes, passing through the intercostal space between the 8th and 9th ribs, to the articulation of the last rib and the xiphoid process. The cannon bone circumference was measured in the middle third of the shin on the left forelimb, formed by metacarpal bones II, III, and IV; the suspensory ligament; and the superficial and deep flexor tendons. The body length was determined as the distance between the cranial portion of the greater tubercle of the humerus and the ischial tuberosity. The metatarsal length was determined as the distance between the proximal and distal epiphysis of the third metatarsal bone. The croup length was determined as the distance between the coxal and ischial tuberosity. The chest width was determined as the distance between the right and left lateral borders of the scapulohumeral joints. The head length was determined as the distance between the ends of the head, from the nuchal crest to the midline of the upper lip edge. The dorsal neck length was determined as the distance between the cranial portion of the dorsal arch of the atlas and the middle third of the cranial border of the scapula. The throat circumference was measured at the level of the atlas region and the inferior insertion of the head and neck junction (Figure 1).
Angular measurements were obtained using an arthrogoniometer: the angle of the scapula was formed between the spine of the scapula and a horizontal line; the croup angle was formed between the straight line of the coxal tuberosity to the greater trochanter of the femur and a horizontal line; and the angle of the hock was formed by the angle of the tibio-tarso-metatarsal joint (Figure 2). Anatomical points were identified and marked with adhesive tape. Height, chest circumference, and cannon bone circumference measurements were taken by ABCCC technicians, while the other measurements were taken by two members of our research team.

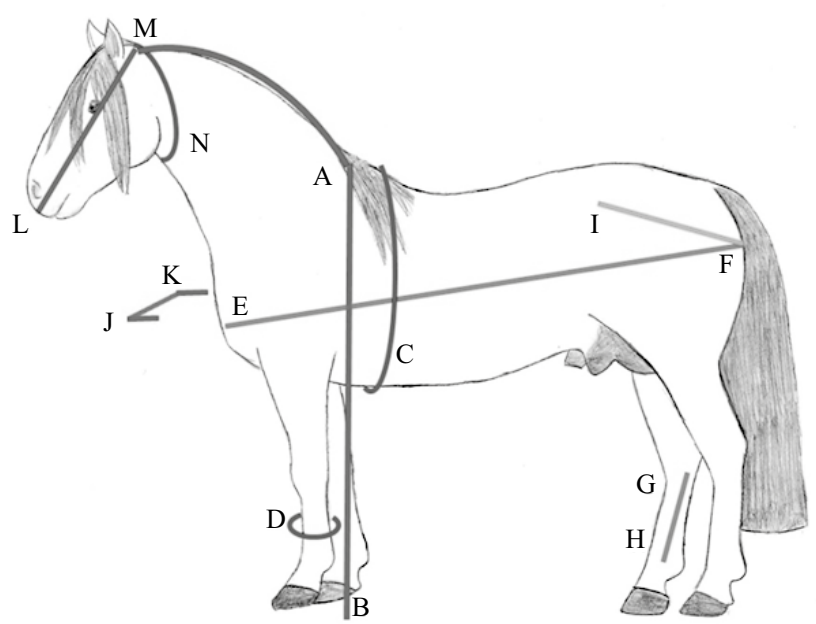

A-B: height; C: chest circumference; D: cannon bone circumference; E-F: body length; G-H: metatarsal length; I-F: croup length; J-K: chest width; L-M: head length; M-A: dorsal neck length; $\mathrm{N}$ : throat circumference.

Figure 1 - Illustrative image of the linear measurements evaluated in this study.

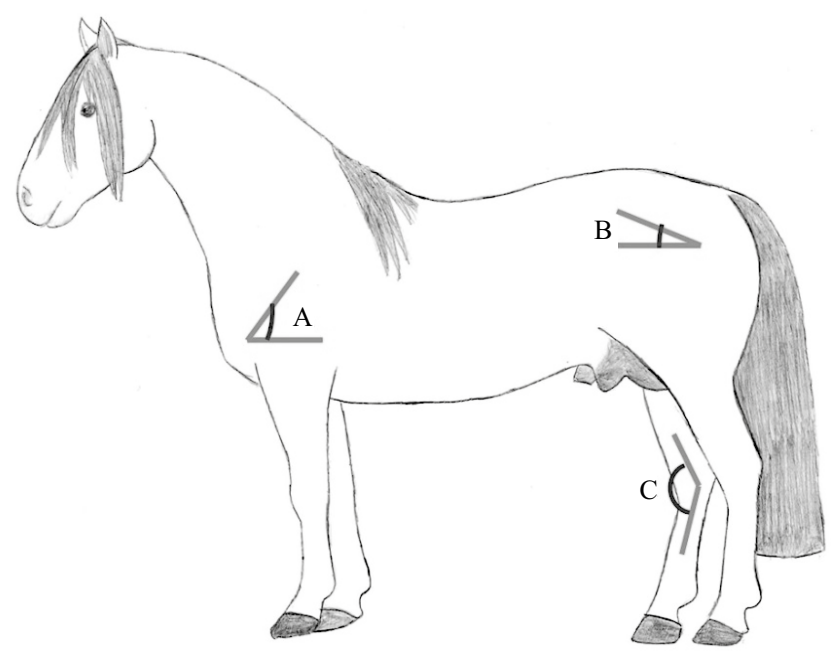

A: angle of the scapula; B: angle of the croup; C: angle of the hock.

Figure 2 - Illustrative image of the angular measurements evaluated. 
In addition to sex effects, all traits were evaluated in relation to the age of the horses. Thus, they were classified as younger (less than seven years of age) or older (more than seven years of age) competing horses. For each trait, differences between means based on sex (male or female) and age (younger or older) were compared by performing Student's t-test, using the $\mathrm{R}$ program (R Core Team, 2016). Results were considered statistically significant when $\mathrm{P}<0.05$.

\section{Results}

Horses that participated in the Freio de Ouro competition showed some variability in the measured morphological traits, although little difference was found between male and female Criollo horses.
The average cannon bone circumference was significantly greater $(\mathrm{P}=0.0241)$ in males $(19.76 \pm 0.68 \mathrm{~cm})$ than in females $(18.95 \pm 0.63 \mathrm{~cm})$ (Table 1). In addition to cannon bone circumference, throat circumference was the only measure that differed significantly $(\mathrm{P}=0.0403)$ between males $(77.66 \pm 3.26)$ and females $(73.30 \pm 3.75 \mathrm{~cm})$. The other evaluated traits did not show significant difference between genders $(\mathrm{P}>0.05)$.

The age of horses participating in the Freio de Ouro competition ranged from 4 to 13 years, with a mean age of seven years. Younger animals $(<7$ years of age) accounted for $54 \%$ of the competition horses, whereas older animals ( $>7$ years of age) accounted for $46 \%$. Statistical analysis showed that height and the other evaluated measures did not differ between younger and older competing horses $(\mathrm{P}>0.05)$ (Table 2).

Table 1 - Morphometric measurements of horses participating in qualifying and final Freio de Ouro 2011 and 2012 competitions

\begin{tabular}{|c|c|c|c|c|c|c|c|c|}
\hline \multirow{2}{*}{ Linear variable } & \multicolumn{4}{|c|}{ Male } & \multicolumn{4}{|c|}{ Female } \\
\hline & $\mathrm{N}$ & Means $(\mathrm{cm})$ & SD & Min-max $(\mathrm{cm})$ & $\mathrm{N}$ & Means $(\mathrm{cm})$ & SD & $\operatorname{Min}-\max (\mathrm{cm})$ \\
\hline Height & 322 & $141.73 \mathrm{a}$ & 1.7 & $140.0-147.50$ & 312 & $141.41 \mathrm{a}$ & 2.13 & $138.00-148.00$ \\
\hline Chest circumference & 322 & $175.4 \mathrm{a}$ & 3.74 & $168.0-186.0$ & 312 & $177.17 \mathrm{a}$ & 3.45 & $169.00-187.00$ \\
\hline Cannon bone circumference & 322 & $19.76 \mathrm{a}$ & 0.68 & $18.00-22.00$ & 312 & $18.95 b$ & 0.63 & $17.50-21.00$ \\
\hline Body length & 304 & $163.38 \mathrm{a}$ & 4.36 & $152.00-174.00$ & 304 & $165.12 \mathrm{a}$ & 5.23 & $154.00-185.50$ \\
\hline Metatarsal length & 247 & $20.75 \mathrm{a}$ & 1.01 & $17.50-23.50$ & 248 & $20.84 \mathrm{a}$ & 1.14 & $18.00-29.50$ \\
\hline Croup length & 254 & $56.88 \mathrm{a}$ & 3.09 & $51.50-77.00$ & 243 & $56.64 \mathrm{a}$ & 2.66 & $50.00-68.50$ \\
\hline Chest width & 284 & $41.38 \mathrm{a}$ & 1.66 & $38.00-46.50$ & 283 & $40.49 \mathrm{a}$ & 2.11 & $35.00-48.00$ \\
\hline Head length & 300 & $64.26 \mathrm{a}$ & 2.54 & $57.50-74.50$ & 292 & $63.56 \mathrm{a}$ & 2.13 & $59.50-70.00$ \\
\hline Dorsal neck length & 305 & $80.01 \mathrm{a}$ & 5.64 & $59.00-96.00$ & 305 & $78.63 a$ & 5.66 & $64.00-94.50$ \\
\hline Throat circumference & 308 & $77.66 \mathrm{a}$ & 3.26 & $66.50-87.50$ & 303 & $73.30 \mathrm{~b}$ & 3.74 & $66.00-84.50$ \\
\hline Angular variable & & Mean $\left(^{\circ}\right)$ & & & & Means $\left({ }^{\circ}\right)$ & & \\
\hline Croup angle & 300 & $22.37 \mathrm{a}$ & 4.47 & $13.00-39.00$ & 301 & $22.21 \mathrm{a}$ & 4.93 & $11.00-38.00$ \\
\hline Scapula angle & 305 & $59.73 a$ & 5.41 & $45.00-71.00$ & 304 & $61.2 \mathrm{a}$ & 6.01 & $30.00-74.00$ \\
\hline Hock angle & 286 & $152.61 \mathrm{a}$ & 5.58 & $129.00-168.00$ & 295 & $152.97 \mathrm{a}$ & 4.49 & $139.00-169.00$ \\
\hline
\end{tabular}

Min-max - minimum-maximum; SD - standard deviation.

The values within the row that are followed by different letters are significantly different by statistics $(\mathrm{P}<0.05)$.

Table 2 - Age effect on morphometric measures of horses participating in qualifying and final Freio de Ouro 2011 and 2012 competitions

\begin{tabular}{|c|c|c|c|c|c|c|}
\hline \multirow{2}{*}{ Linear variable } & \multicolumn{3}{|c|}{$<7$ years } & \multicolumn{3}{|c|}{$>7$ years } \\
\hline & $\mathrm{N}$ & Means $(\mathrm{cm})$ & $\mathrm{SD}$ & $\mathrm{N}$ & Means $(\mathrm{cm})$ & $\mathrm{SD}$ \\
\hline Height & 340 & $141.79 \mathrm{a}$ & 1.90 & 293 & $141.33 \mathrm{a}$ & 1.95 \\
\hline Chest circumference & 340 & $176.66 \mathrm{a}$ & 3.66 & 293 & $175.82 \mathrm{a}$ & 3.72 \\
\hline Cannon bone circumference & 340 & $19.35 \mathrm{a}$ & 0.77 & 293 & $19.37 \mathrm{a}$ & 0.78 \\
\hline Body length & 329 & $164.72 \mathrm{a}$ & 4.73 & 279 & $163.7 \mathrm{a}$ & 5.03 \\
\hline Metatarsal length & 276 & $20.93 a$ & 1.19 & 219 & $20.62 \mathrm{a}$ & 0.90 \\
\hline Croup length & 282 & $56.79 \mathrm{a}$ & 2.73 & 215 & $56.72 \mathrm{a}$ & 3.08 \\
\hline Chest width & 322 & $40.89 \mathrm{a}$ & 1.94 & 244 & $40.99 \mathrm{a}$ & 1.97 \\
\hline Head length & 330 & $63.97 \mathrm{a}$ & 2.43 & 261 & $63.84 \mathrm{a}$ & 2.31 \\
\hline Dorsal neck length & 331 & $79.44 \mathrm{a}$ & 5.33 & 268 & $79.14 \mathrm{a}$ & 6.11 \\
\hline Throat circumference & 340 & $75.5 \mathrm{a}$ & 3.98 & 270 & $75.4 \mathrm{a}$ & 4.30 \\
\hline Angular variable & \multicolumn{3}{|c|}{ Means $\left(^{\circ}\right)$} & \multicolumn{3}{|c|}{ Means $\left({ }^{\circ}\right)$} \\
\hline Croup angle & 327 & $21.93 \mathrm{a}$ & 4.43 & 274 & $22.73 \mathrm{a}$ & 5.01 \\
\hline Scapula angle & 340 & $60.55 \mathrm{a}$ & 5.67 & 267 & $60.36 \mathrm{a}$ & 5.88 \\
\hline Hock angle & 327 & $152.85 \mathrm{a}$ & 4.61 & 254 & $152.72 \mathrm{a}$ & 5.56 \\
\hline
\end{tabular}

SD - standard deviation.

The values within the row that are followed by different letters are significantly different by statistics $(\mathrm{P}<0.05)$. 


\section{Discussion}

Animals advancing to the qualifying and final events of this competition are considered excellent horses, considering the morphological patterns required by the $\mathrm{ABCCC}$, their ability to work with cattle, and their agreeability for being ridden.

The heights of the animals were close to the minimum values required for the breed standard (at least $140 \mathrm{~cm}$ for males and $138 \mathrm{~cm}$ for females). This result was similar to those of Kurtz Filho and Löf (2007), who evaluated the height, chest circumference, and cannon bone circumference of 2,054 Criollo horses participating in the morphological evaluation contest at the Expointer annual exhibition, in Esteio, RS, Brazil, from August 1993 to August 2002. They identified males of an average height of $143 \pm 2 \mathrm{~cm}$ and females of an average height of $142 \pm 2 \mathrm{~cm}$, emphasizing that the height of this breed may be lowering over time.

The decline in the average height is believed be due to the use of Chilean stallions in Brazil in the early 1970s (Dalto, 2006), with a subset of animals adapted mainly for the Media Luna competition. These animals are shorter than the breed standard, with an average height of $137.4 \mathrm{~cm}$ for males and $137.7 \mathrm{~cm}$ for females at the age of three years (Porte, 2000). According to the Federation of Criollo Horses Breeders of Chile, the average height of all horses classified in the final of Media Luna competition was $139.8 \mathrm{~cm}$ (Dowdall and Flores, 2016). The authors evaluated the biometric trends of great Criollo champions in Argentina between 2004 and 2015 and found that height declined by $0.11 \mathrm{~cm}$ per year in these animals, which represents a total reduction of $1.32 \mathrm{~cm}$ in height during the 12 years analyzed. According to the authors, one of the causes for this reduction is that the harmony judgment and evaluation of smaller animals is easier, but they emphasize the need to continue monitoring the progress of this measure and to penalize further declines in height.

The average height of the Campeiro breed was $144 \mathrm{~cm}$ (McManus et al., 2005), slightly taller than the Criollo breed, and the Pantaneiro breed was $138 \mathrm{~cm}$ on average (a little shorter) (Miserani et al., 2002). Although both Brazilian breeds share the same origin, South American horse breeds have unique characteristics, shaped by geography, type of work, and technical orientation. The Quarter Horse breed has different bloodlines due to different selection objectives. Quarter Horse racing lines presented an average height of $155 \mathrm{~cm}$, while working/ functional competition lines presented an average height of $146 \mathrm{~cm}$ (Meira et al., 2013). A similar value of $145 \mathrm{~cm}$ for working Quarter Horses was found by Ramos et al. (2014). The Mangalarga Marchador breed is the tallest of the Brazilian breeds, with a height of $151.5 \mathrm{~cm}$ for adult males and $151.6 \mathrm{~cm}$ for females (Cabral et al., 2004), although Zamborlini et al. (1996) reported a lower average height of $146 \mathrm{~cm}$.

Subjective observations indicating that animals of the Criollo breed are decreasing in size were not confirmed in this study. The height did not differ $(\mathrm{P}>0.05)$ between younger ( $<7$ years old) and older ( $>7$ years old) competing horses, with means and standard deviations of $141.79 \pm 1.90$ and $141.33 \pm 1.95 \mathrm{~cm}$, respectively (Table 2). These results differ from those of Kurtz Filho and Löf (2007), in which younger adult animals were shorter than older animals, as a result of their smaller Chilean ancestors. It is possible that this phenomenon was not identified in this study due to the short evaluation period of only two years; therefore, it is necessary to continue monitoring this measurement to analyze its progress, since both technicians and breeders are concerned about the height of this breed.

Chest circumference is associated with genetic, nutritional, and physical conditioning factors. Males and females presented similar chest circumferences $(175.39 \pm 3.74$ and $177.17 \pm 3.45 \mathrm{~cm}$, respectively) (Table 1). These measurements were in accordance with the minimum standards of the breed of $168 \mathrm{~cm}$ for males and $170 \mathrm{~cm}$ for females. According to the ABCCC (2016), the chest should be broad, wide, and deep, with well-separated and muscular intercostal spaces and arched deep ribs. These measurements are slightly smaller than the values for the Criollo horses that participated in the morphological evaluation contest at the Expointer, as recorded by Kurtz Filho and Löf (2007), who found an average chest circumference of $180 \mathrm{~cm}$ for females and $179 \mathrm{~cm}$ for males. This result probably reflects the fact that these animals were prepared for morphological competition, which requires a different type of preparation and larger quantities of food than for athletic competitions, such as the Freio de Ouro competition. The average chest circumference of the Campeiro breed was $173 \mathrm{~cm}$, and there was a considerable gender influence. Females showed greater measurements $(174.4 \mathrm{~cm})$ than males $(167.2 \mathrm{~cm})$ (McManus et al., 2005), despite the claim of the author that the males engaged in more physical activity. The Pantaneiro breeds showed a greater chest circumference in males (Miserani, 2001), as did the Mangalarga Marchador breed, with the chest circumference of adult males being $180.8 \mathrm{~cm}$ and that of females being $175.7 \mathrm{~cm}$ (Cabral et al., 2004). The average value found by Lage et al. (2009) for the same breed was $177 \mathrm{~cm}$. In this study, this finding probably indicates a 
tendency to start competitions using animals with a better body score to achieve a better morphological result.

The cannon bone circumference was greater in males than in females $(19.76 \pm 0.68$ vs. $18.95 \pm 0.63 \mathrm{~cm}$, respectively) $(\mathrm{P}=0.0241)$. These values were similar to the measurements of $20 \mathrm{~cm}$ for males and $19 \mathrm{~cm}$ for females found by Kurtz Filho and Löf (2007). According to the breed standard, the shin should be short and upright, with strong and defined tendons. The minimum measurement required for registry confirmation is $18 \mathrm{~cm}$ for males and $17 \mathrm{~cm}$ for females. Pimentel et al. (2017) evaluated Criollo colts from birth to three years of age and found that males reached the minimum requirement for registration at 18 months of age, while females reached the minimum requirement for registration, on average, at 11 months of age. Males presented greater cannon bone circumferences. In addition, males entering the Freio de Ouro competition also had a greater throat circumference than females ( $77.66 \pm 3.26$ vs. $73.30 \pm 3.75 \mathrm{~cm}$, respectively) $(\mathrm{P}=0.0403), 4.36 \mathrm{~cm}$ on average (Table 1). These are traits that are probably related to gender and influenced by hormones. According to Cunnigham (1993), testosterone not only stimulates muscular development but also favors bone growth.

Body length did not differ between males and females $(163.38 \pm 4.37$ vs. $165.12 \pm 5.2 \mathrm{~cm}$, respectively), and no previous studies have reported significant genderbased differences in body length in the Criollo breed. Morphology has been studied in other Brazilian saddle breeds originating from Berber horses, all of which present shorter body lengths than does the Criollo breed. The Campeiro breed averaged $147 \mathrm{~cm}$ (McManus et al., 2005), and the Mangalarga Marchador breed averaged $155.55 \mathrm{~cm}$ (Ramos et al., 2014). Another study with the Mangalarga Marchador breed showed that males were longer bodied than females, with an average of $157.6 \pm 6.1 \mathrm{~cm}$ for males and $149.4 \pm 12.2 \mathrm{~cm}$ for females (Cabral et al., 2004). Racing lines of the Quarter Horse breed were longer and had an average length of $180 \mathrm{~cm}$, while working lines had an average length of $163 \mathrm{~cm}$ (Meira et al., 2013). Participants in the Vaquejada competition showed an average of $149.52 \mathrm{~cm}$ (Meneses et al., 2014), and working and riding Quarter Horse animals had an average length of $150.33 \mathrm{~cm}$ (Ramos et al., 2014). The average length of horses entered into barrel-racing events was $154.50 \mathrm{~cm}$ (Donofre et al., 2014).

The ideal saddle horse should have similar measurements for body length and height at the withers (Solanet, 1946; Dowdall, 1982; Torres and Jardim, 1987), which characterizes the mediolinear horse. Animals participating in the Freio de Ouro competition presented an average height of $141.6 \mathrm{~cm}$, compared with the average body length of $164 \mathrm{~cm}$. Thus, the study population horses were, on average, $23.4 \mathrm{~cm}$ longer than they were tall, a typical characteristic of longilinear horses. According to Dowdall (1982), 30 Criollo horses participating in exhibitions at Palermo (Argentina) in the Marcha de Resistência and Raid were $144.3 \mathrm{~cm}$ tall and $149.9 \mathrm{~cm}$ long on average, respectively, a difference of only $5.6 \mathrm{~cm}$, similar to mediolinear horse measurements. Racing lines of Quarter Horse breed also showed a difference of $24 \mathrm{~cm}$ in the relationship between the average body length $(180 \mathrm{~cm})$ and height at the withers $(156 \mathrm{~cm})$. These racing bloodlines are different $(\mathrm{P}<0.05)$ from working lines regarding the average length $(163 \mathrm{~cm})$ and height $(146 \mathrm{~cm})$. The body length for the working line was, on average, $17 \mathrm{~cm}$ greater than the height (Meira et al., 2013), showing a clear relationship between the physical characteristics and the animal function, as in the Criollo breed.

The dorsal neck length was similar between genders, with an average of $80.01 \pm 5.6 \mathrm{~cm}$ for males and $78.63 \pm 5.6$ $\mathrm{cm}$ for females. A similar value of $78.2 \mathrm{~cm}$ was found for the Arabian breed (Sobczuk and Komosa, 2012), in which the neck length was highly associated with morphological beauty and was also important for forelimb movement. Strong neck muscles control the action of the shoulder, arm, and forearm muscles, releasing forelimbs with more agility (Denoix, 2014). Compared with the Mangalarga Marchador breed, these adult horses have shorter necks and presented average values of $66.9 \mathrm{~cm}$ for males and $63.3 \mathrm{~cm}$ for females (Cabral et al., 2004). The angle of the scapula was also similar, with an average of $59.73 \pm 5.4^{\circ}$ for males and of $61.2 \pm 6.0^{\circ}$ for females. The overall average was $60^{\circ}$, differing from the results of Dowdall (1982), who reported that the inclination of the scapula over the horizontal line varied by approximately $50^{\circ}$ in Criollo horses. According to Monina (2006), an angle of $45^{\circ}$ enables the step length and height at the withers to present with a similar measurement, which results in greater gait amplitude and performance. Greater angles (i.e., more vertical or less inclined scapulae) reduce the amplitude of the step, according to Souza (1998), probably because the oblique scapula absorbs the impact of the hoof on the ground better, resulting in greater cushion and softness during movement (Jones, 1987).

Neither croup length nor angle differed between males and females (Table 1). According to the ABCCC (2016), the croup should be muscular, strong, well developed, medium in width and length, and slightly inclined, but these measurements have not been defined numerically. 
In this study, the average croup length was $56.7 \mathrm{~cm}(50.0$ minimum $/ 77.0 \mathrm{~cm}$ maximum). According to Sobczuk and Komosa (2012), long croups significantly impact motor performance and speed test results. The average croup angle was $22.2^{\circ}\left(11^{\circ}\right.$ minimum $/ 39^{\circ}$ maximum), similar to the angle of inclination of $23^{\circ}$ mentioned by Pons (1993), but smaller than the $30^{\circ}$ mentioned by Dowdall (1982) for Criollo horses. Although no significant differences $(\mathrm{P}>0.05)$ were found between the mean croup angles of younger versus older animals (Table 2), the means of $21.93^{\circ}$ (younger animals) and $22.73^{\circ}$ (older animals) observed in this study indicated a trend towards more horizontal croup angle, which can be confirmed in future evaluations considering a longer observation period.

The metatarsal length did not differ between Criollo horses of differing gender (Table 1) or age (Table 2) and was, on average, $20.8 \pm 1.0 \mathrm{~cm}$, shorter than the length of $27 \mathrm{~cm}$ documented by Dowdall (1982). In the Arabian breed, the average value was $41.4 \mathrm{~cm}$. A longer metatarsus is associated with greater motor efficiency, a greater predisposition to galloping (Sobczuk and Komosa, 2012), and the ability to make quick turns and abrupt stops (Meneses et al., 2014). This ability may contribute to a better execution of some movements, as evidenced by the improved performances year after year in the Freio de Ouro competition.

The average angle of the hock was $152.8 \pm 0.29^{\circ}$ and did not differ between males and females. The breed standard states that the anterior angle of the hock should be "moderately" open, requiring judges to make subjective decisions. Our measurement provides specific information that enables judges and technicians to select animals with greater objectivity.

Although the concept of perfect conformation varies among breeds, the consensus view holds that morphological beauty results when all parts of the body are brought together harmoniously, symmetrically, and in proportion to the size of the body (Torres and Jardim, 1987; Ensminger, 1978; Souza, 1998; McManus et al., 2008), while following the breed standard. In this context, the isolated evaluation of these measurements may not enable quality judgments to be made on specific animals, but the data represent valuable support for selection to refine the breed and for providing an objective basis for the decisions of judges.

\section{Conclusions}

Our findings suggest that animals are near to minimum height limits required for the definitive registration in
Criollo breed. The cannon bone circumference is greater in males; however, slim throat is observed in females. The evaluated measures do not differ in Criollo horses less or more than seven years old in Freio de Ouro competitions.

\section{Acknowledgments}

The authors thank the Associação Brasileira de Criadores de Cavalos Crioulos (ABCCC), for the financial and technical support, and Dr. Gabriel de Marco Flório, Dr. Ibsen Votto, Dr. Rodrigo Teixeira, Dr. Mário Móglia Suñe, and Dr. Manuel Luís Benevenga Sarmento, for assistance in data collection.

\section{References}

ABCCC - Associação Brasileira de Criadores de Cavalos Crioulos. 2016. Regulamento do Serviço de Registro Genealógico e Regulamento do Registro de Mérito. Associação Brasileira de Criadores de Cavalos Crioulos, Pelotas.

Affonso, A. and Correa, S. 1992. Cavalo Crioulo uma história de raça. Sagra, Porto Alegre. 210p.

Beeman, G. M. 2008. Conformation of the horse: relationship of form to function. p.63-68. In: Annual convention of the American Association of Equine Practitioners. AAEP, San Diego, CA.

Cabral, G. C.; Almeida, F. Q.; Quirino, C. R.; Pinto, L. F. B.; Santos, E. M. and Corassa, A. 2004. Avaliação morfométrica de equinos da raça Mangalarga Marchador: medidas lineares. Revista Brasileira de Zootecnia 33:989-1000. https://doi.org/10.1590/S1516-35982004000400019

Cunnigham, J. G. 1993. Tratado de fisiologia veterinária. GuanabaraKoogan, Rio de Janeiro.

Dalto, R. 2006. Freio de Ouro, uma história a cavalo. Associação Brasileira de Criadores de Cavalos Crioulos, Pallotti, Santa Maria. $176 \mathrm{p}$.

Denoix, J. M. 2014. Biomechanics and physical training of the horse. CRC Press, Boca Raton, FL.

Donofre, A. C.; Pouoli Filho, J. N. P.; Ferreira, I. E. P.; Mota, M. D. S. and Chiquitelli Neto, M. 2014. Equilíbrio de cavalos da raça Quarto de Milha participantes da modalidade de três tambores por meio de proporções corporais. Ciência Rural 44:327-332. https://doi.org/10.1590/S0103-84782014000200021

Dowdall, C. and Flores, L. 2016. Tendencias biométricas em la raza Crioulla 2004-2015: Luz amarilla para la alçada. Available at: $<$ http://www.caballoscriollos.com/_recursos/archivos/tendencias_ biometricas.pdf $>$. Accessed on: Fev. 2, 2016.

Dowdall, R. C. 1982. Criando Criollos. Hemisferio Sur, Montevideo.

Ensminger, M. E. 1978. Produccion equina. Libreria El Ateneu, Buenos Aires.

Jones, W. E. 1987. Genética e criação de cavalos. Roca, São Paulo.

Kurtz Filho, M. and Löf, H. K. 2007. Biometric in Brazilian Criollo breed. Archives of Veterinary Science 12:47-51.

Lage, M. C. G. R.; Bergmann, J. A. G.; Procópio, A. M.; Pereira, J. C. C. and Biondini, J. 2009. Associação entre medidas lineares e angulares de equinos da raça Mangalarga Marchador. Arquivo Brasileiro de Medicina Veterinária e Zootecnia 61:968-979. https://doi.org/10.1590/S0102-09352009000400027

Lima, R. A. S. and Cintra, A. G. 2015. Revisão do estudo do complexo do agronegócio do cavalo. Ministério da Agricultura, Brasília, DF. 
Mawdsley, A.; Kelly, E. P.; Smith, F. H. and Brophy, P. O. 1996. Linear assessment of the thoroughbred horse: an approach to conformation evaluation. Equine Veterinary Journal 28:461-467.

McManus, C.; Falcão, R. A.; Spritze, A.; Costa, D.; Louvandini, H.; Dias, L. T.; Teixeira, R. A.; Rezende, M. J. M. and Garcia, J. A. S. 2005. Caracterização morfológica de equinos da raça Campeiro. Revista Brasileira de Zootecnia 34:1153-1562. https://doi.org/10.1590/S1516-35982005000500015

McManus, C.; Santos, S. A.; Silva, J. A.; Louvandini, H.; Abreu, U. G. P.; Sereno, J. R. B. and Mariante, A. S. 2008. Body indices for the Pantaneiro horse. Brazilian Journal Veterinary Research Animal Science 45:362-370.

Meira, C. T.; Curi, R. A.; Silva, J. A. V.; Corrêa, M. J. M.; Oliveira, H. N. and Mota, M. D. S. 2013. Morphological and genomic differences between cutting and racing lines of Quarter Horses. Journal of Equine Veterinary Science 33:244-249. https://doi.org/10.1016/j.jevs.2012.07.001

Meneses, A. C. A.; Costa, M. D.; Maruch, S.; Moreira, P. R. and Martins Neto, T. 2014. Medidas lineares e angulares de animais da raça Quarto de Milha utilizados em uma prova de vaquejada. Revista Brasileira Ciência Veterinária 21:256-261.

Miserani, M. G. 2001. Variação genética, fenotípica e caracterização do cavalo Pantaneiro. Dissertação (M.Sc.). Universidade de Brasília, Brasília, DF.

Miserani, M. G.; McManus, C.; Santos, S. A.; Silva, J. A.; Mariante, A. S. and Abreu, U. G. P. 2002. Avaliação dos fatores que influem nas medidas lineares do Cavalo Pantaneiro. Revista Brasileira de Zootecnia 31:335-341. https://doi.org/10.1590/S1516-35982002000200007

Monina, I. 2006. Biomecánica equina. p.177-195. In: Fisiologia del ejercicio en equinos. Boffi, F. M., ed. Inter-Médica, Buenos Aires.
Pimentel, A. M. H.; Rodrigues, W. B.; Martins, C. F.; Montanez, N. R.; Boligon, A. A. and Souza, J. R. M. 2017. Gender on the growth of Criollo foals from birth to three years of age. Ciência Rural 47:e20150989. https://doi.org/10.1590/0103-8478cr20150989

Pons, D. S. 1993. O cavalo Crioulo: seis décadas de experiência. Livraria e Editora Agropecuária Ltda, Guaíba. 141p.

Porte, E. 2000. Crecimiento e desarrollo del caballo criollo chileno. Avances en Producción Animal 25:167-177.

R Core Team. 2016. R: A language and environment for statistical computing. R Foundation for Statistical Computing, Vienna, Austria. Available at: $<$ https://www.R-project.org/>. Accessed on: Mar. 7, 2018.

Ramos, T. N. M.; Cardoso, D.; Oliveira, J. V. and Bomfim, C. A. D. M. 2014. Características zoométricas de equinos de raças definidas e não definidas criadas na região de Araçatuba, SP. Boletim de Indústria Animal 71:7.

Sobczuk, D. and Komosa, M. 2012. Morphological differentiation of Polish Arabian Horses: multivariate analysis. Bulletin of the Veterinary Institute in Pulawy 56:623-629.

Solanet, E. 1946. Tratado de hipotecnia. Morata, Buenos Aires.

Souza, G. L. 1998. Morfologia: seleção a toda prova. Revista da Associação Brasileira de Criadores de Cavalos Crioulos 40-44.

Torres, A. P. and Jardim, W. R. 1987. Criação do cavalo e outros equinos. Nobel, São Paulo.

Zamborlini, L. C.; Bergmann, J. A. G.; Pereira, C. S.; Fonseca, C. G. and Carneiro, A. S. R. 1996. Estudo genético-quantitativo de medidas lineares de equinos da raça Mangalarga Marchador - I. Estimativas dos fatores de ambiente e parâmetros genéticos. Revista Brasileira de Ciência Veterinária 3:33-37. 